University of Louisville

ThinkIR: The University of Louisville's Institutional Repository

Electronic Theses and Dissertations

1940

\title{
Plasticizing ethylcellulose : Il. Effect of ethylcellulose in spirit varnishes.
}

Ira Walter Hutchison 1914-1996

University of Louisville

Follow this and additional works at: https://ir.library.louisville.edu/etd

Part of the Chemical Engineering Commons

\section{Recommended Citation}

Hutchison, Ira Walter 1914-1996, "Plasticizing ethylcellulose : II. Effect of ethylcellulose in spirit varnishes." (1940). Electronic Theses and Dissertations. Paper 1810.

https://doi.org/10.18297/etd/1810

This Master's Thesis is brought to you for free and open access by ThinkIR: The University of Louisville's Institutional Repository. It has been accepted for inclusion in Electronic Theses and Dissertations by an authorized administrator of ThinkIR: The University of Louisville's Institutional Repository. This title appears here courtesy of the author, who has retained all other copyrights. For more information, please contact thinkir@louisville.edu. 


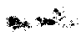 \\ $+2$
}

UNIVERSITY OF LOUISVILLE

I. PLASTICIZIHG ETHTCELLULOSE

II. EFHECT OF ETHXLCELLULOSE IN SPTRIT VARWISHES

\author{
A Thesie \\ Submitted to the Feoulty \\ of tho Graduate Sohool \\ of the University of Loulevilie \\ in Partial Fulfillmont \\ of the Requiroments \\ for the Degree of
}

MASTER OP CHEUTCAL ENGINEERIHG

Departwont of Chomlcal Engineerling

Ira Falter Hutohison, Jr.

1940 
I. PLASTICIZING EMTICELLULOSB

II. EFFECT OF ETHYCELLULOSE IN SPIRIT VARWISHES

Ira Walter Hutohioon, Jr.

Approved by Examining Committoo:

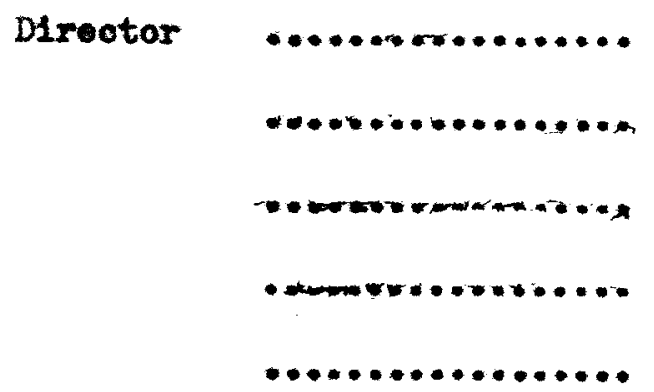

May 23, 1940 
TABLB OF CONTENTS

Page

Acimomledgemont . . . . . . . . . . . 111

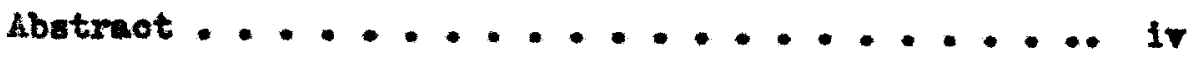

PART I PLASTTCIZIHO ETHTLCELLULOSE

Llst of Tables.............. ri Introduction ............... 1 Historical .............. s Theoretical ............... 5 Raw Material. ............. 8 Experimentel .............. 11 Block Test ............. 13 Print Test ............. 13 Track Tost ............. 14 Data.................. 15 Rosults ............. 27 General ............. 18 Effect of Orange Peeling on Tests ... 21 Hiscellanoous Observations ....... 22 sumary .............. 24 Literature Clted ........... 26

PART II EFFECT OF ETHYLELLULOSE IN SPIRIT VARUISIIES Introduction ............ 29 H1storioal ...................... 31 
TABLE OF CONTEMTS (CONCLUDSD)

Page

Thoorotical ............. 33

Raw thaterials............ 35

Experimental ........... 38

Abration Rosistance ....... 39

Hardnoss ............4 41

Cold Chook ............ 42

volting Point ..........42

Ho1sture Hesistance ........43

Procedure .............. 44

Data ............... 46

Results ............. 48

Abration Resistanco ........ 49

Hardness .......... 49

Cold Chook ........... 49

Nelting Point ......... 49

Nolsture Resistance ....... 49

Literature C1ted .......... 51

Appond1x ................. 53

Aaknowledgoments ............. 56

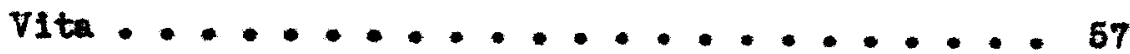




\section{ACKNOWLEDOELEAT}

The Author wishes to acknowledge the Lind assistanoe and helprul guidano

of Dootor R. C. Ernst who dirocted

this research. 
ABSTRACT

\section{PLASTICTZIHG ETHYCELLULOSE}

Varlous percentazes of Beveral plasticlzers were substituted for the ethyloellulose in ethylcellulose-solvent mixtures. Block, print, and "tack by feel" tosts were run. These tests showed that largo percentages of plasticizers could be used in many casea, but the final choice depends upon the application of the finished coating meterial. The application determines vinioh of the three tests are the most signifloant.

liagazine cover are lacguered, and in transportation often stiok together. The block tests provide comperison of the plastiolxers under conditions sindlar to the treationt of the nagazines. The print test would be most significant where there is cloth in contact with a lacquered surface. "Tack by feel" tests are least reliable in determining tackiness of a film.

\section{BFEECT OF ETHYLCLLLULOSE IN SPIRIT VARNISHES}

Various percentages of ethylcellulose were substituted for resin in spirlt varnishes. Splrit varnishes used were made with manila and pontianak resins. Abrasion resistance, hardness, cold check, moisture resistance, and melting point determinations were made in order to find the effect of the ethyloellulose. Experimental work indiosted that the ethyloellulose improved the abrasion resistanoe, hardness, cold check resistanee, and noisture resistance of the spirit varnishes, and increased their nolting points. 
PART I

PLASTICIZIMG ETHYLCELLULOSE 
Table

Pago

I Properties of plasticisers ...... 9

II Properties of ethyleellulose.... 10

II Solvent oombinations ......... 12

IV Lindts of plasticieor concentration standard othoxy othyloellulose . 16

$\checkmark$ Lints of plastloizer ooneentration modiun ethoxy ethylcellulose ... 16

VI Limlts of plestieleer conoentration Iow ethoxy ethyloellulose.... 16

VII Speolal solvent combinations .... 22 
INPRODUCTION 
The purpose of this investigation was to determine the quantity of plastiolzer that could be used in ethylcellulosesolvent mixtures without having the resulting films remin tecky or atioky after a reasonable drying, time.

The use of fairly largo amounts of plasticleers would provide a distinct price advantage because most of the plasticizers are less expensive than the cellulose derivative. Elongation of the film would be increased in some cases without materially reducIng the yeld point. A great many afferent types of plasticizers are on the arket, consequently, the cholce would not be linited. The limits of concentrations of plasticizers that could be used without the resultin; films remeining taoly over a certain period of time have been established. This was done by employing blook. print, and "tack by fool" teats.

Results of the experimental work are given, and indicate possible use of large concentrations of plasticizers. 
HISTORICAL 
Plasticizers have always been used in order to increase the tens1le otrength and elongation of lacguer fllms. The use of the plasticleor as a jor part of the film-forming materials, how ever, is of more recent date.

Base and Kauppl $(1,2)$ have shown by load-elongation curves that increasing the v1scosity of ethylcellulose does not appreciably affect the yleld point of films of the same plasticizer content. The inorease in tensile strength and toughnes: becomes greater as larger percentages of plasticisers are used with higher viscosity material. Kraus (3) found by studying plasticizers in nitrocellulose lacquers, that plasticizers which impart favorable weathering properties are those that also prevent ultraviolet light from being dotrimental to the physical properties of the filns. He showed that the poorest weathering properties of plasticised films were observed when plasticizers containing lonf aliphatio carbon chains were used, while favorable properties were observed whon aromatic groups were used. Van Houckeroth (4) found that plasticieers aro probably more important than resins in extending the durability of lacquers, although the favorable effect of the resins upon gloss and adhesion are significant. 
THEORLPICAL 
A portion of a volotile solvent vill remain in a film for a long time imparting to the film a certain anount of plastiolty. After an indefinite period only a very all anount of the volatile solvent wil be left and the film becomes brittio. To overoome or regulate this brittleness plasticleers or softeners are used. These materials, whother 11quid or solid, are virtually nonvolatile.

Non-volatility, then, la one of the most important properties of a plasticiser. Other desirable characteristios are resistance to molsture, atrospheric oxidation. 11 ght and moderate hoat, miscibility and non-reectivity with cellulose derivatives, resins, and solvents; non-insoibillty with waters neutrallty, and laok of color and pronouncod odor.

Plasticisers affect the "secondary flow" and consequently the glose of the film.

Llquid plasticizers are coneldered more desirable than solid plastioizers. One explanation for this is that solid plastlolzers aight crystallize from the film when used under unfavorable conditions. Such is the onse with triphenyl phosphate. The resson for this condition is that the temperature of the solution at the critloul point is above the atmospheric temperature and the amount of softener is in excess of that which can be held in stablo oolution at that temperature. This condition may be remedied by using aller amounts of plasticizers or adding another plasticizer, the critical oolution temperature of which is well below the atmospherio temperature. 
The action of a plasticizer in a filn depends upon the concentration of the plasticieing materiel present. This was shown by previous investigation of Bass and Kauppi $(1,2)$. The plasticizer at low ooncontration seers to act as a flexiblo adhesivo between the molecules of the cellulose chain. Inorease of plastlolzer concentration causes the molecules to become surrounded by the fluld and the plasticizer aots as a lubricant. The chaine of ethylcellulose are thus separated and the film weakened with a consequent reduction of yield polnt. This reduotion of yield point in some cases is considerable. Increese of complexity of the molecule of a plastielzer in a given series causes the yield point to become higher. 
RAW WATEEIALS 
The raw materials ueed in this imvestigation included ten different plastioleses thylcellulose of standard. wadiun, and $10 \mathrm{w}$ ethory grade; toluone and ethyl alcohol.

The properties and souroe of the plastioisers used are given in the foll wing tables

TABLE I

PROPERTIES OF PLASTICIZERS*

\begin{tabular}{|c|c|c|c|c|}
\hline Plactielzer & Souros & $\begin{array}{l}\text { Bolling } \\
\text { Range } \\
\text { oc }\end{array}$ & $\begin{array}{l}\text { Holting } \\
\text { Point } \\
{ }^{\circ} \mathrm{C}\end{array}$ & $\begin{array}{l}\text { Speoific } \\
\text { orarity }\end{array}$ \\
\hline Dor Plast101ser 6 & Dow Chom. Co. & 280 & - & 1.230 \\
\hline $\begin{array}{l}\text { Trloresyl } \\
\text { Phoophate }\end{array}$ & Monsanto Chom. Co & $\begin{array}{r}235 \\
+\quad t 0 \\
265\end{array}$ & 18 & 1.18 \\
\hline $\begin{array}{l}\text { Triphonyl } \\
\text { Phosphata }\end{array}$ & Dow Chom. Co. & $\$ 68$ & 49.9 & 1.185 \\
\hline D1butyl Phthalate & $\begin{array}{l}\text { J. S. Ind. Chese. } \\
\text { Ine. }\end{array}$ & $\begin{array}{r}195 \\
\text { to } \\
200\end{array}$ & - & 1.043 \\
\hline Diphonyl Phthelate & Honsanto Chem.Co. & $\begin{array}{r}250 \\
\text { to } \\
257\end{array}$ & 70 & $\rightarrow$ \\
\hline Castor 011 & No information ar & allablo & & \\
\hline Cocoamut 011 & Wo information av & allable & & \\
\hline $\begin{array}{l}\text { Blom Linseed } 011 \\
\text { (No. 100) }\end{array}$ & $\begin{array}{l}\text { Aroher-Dantele- } \\
\text { Atdand }\end{array}$ & - & - & 0.997 \\
\hline $\begin{array}{c}\text { Blom Castor o11 } \\
\text { (Pale Ho. 16) }\end{array}$ & $\begin{array}{l}\text { Baker Castor } 011 \\
\text { Co. }\end{array}$ & - & - & $\begin{array}{r}1.080 \\
t 0 \\
1.040\end{array}$ \\
\hline Butyl stearate & - & $\begin{array}{r}220 \\
\text { to } \\
360\end{array}$ & 19.5 & $\begin{array}{r}0.856 \\
t 0 \\
0.857\end{array}$ \\
\hline
\end{tabular}

- Boe Gardner. "Physical \& Chomioal Exnination of Paints, Varnishes. Laequers and Colors", 9th Edit1on, pages 633, 575-578 for epecifle conditlons. 
The ethyloellulose was supplled by the Dow Chemical Company and had the following properties:

TABLE II

PROPERTIES OF ETHYLCELLULOSE

Ethory Type

Ethory oontent

Viscosity, cent1poises

Softening point, ${ }^{\circ} \mathrm{C}$

Molting point, ${ }^{\circ} \mathrm{C}$
Standard Hodiun Low

$48.5 \%$ to $49.5 \% 45.0 \%$ to $46.5 \% \quad 41.0 \%$ to $45.0 \%$

20

20

20

138 to 133

155 to 145

205 to 150

173 to 165

195 to 185

210 to 200

The othyl alcohol had speoifle gravity of 0.789 and boillng polnt of $78.4^{\circ} \mathrm{C}$.

The tolueno had specifie gravity of 0.866 and a boiling point of $112^{\circ} \mathrm{C}$

The paper ueed in the block and tack tests was special highgloss paper, and in the print tests was kimpec paper. 
EXPERIHENAL 
Varlous methods, suoh as block, print, and "tack by foel". have been used previously to determine whother or not a film is dry. Block tests are less universal than the other two, and consist in folding a paper on whioh the filn has been cast so that the paint film are adfecent. In print tests, a rough cloth 18 placed over the film and woight is applied. Probably the most widely used, and certainly the least reliable, in a quantitative sense, 1s the "tack by foel" mothod. The result in this oase is complicatod by many factors such as molsture on the hands, humidity, condition of surface. These three tosts were enployed in this irvostlgation in the nanner described below.

The solutions were made up to $20 \%$ solids by weight and allowed to ralx thoroughly on a tumbling mill untll they were homogeneous. The amount of plastioiser was caloulated as percentage of total solide. After selection of atarting percentage, more or less plasticizer was used in the following solution depending upon whether the individual tests gave satisfactory or unsatisfactory rosults. Solvents used were in the following proportions by volume:

\section{TABLE III}

SOLVENT COABIRATIONS

Percent Toluene

Standard Ethoxy

Lodfum Ethoxy

Low Ethoxy
80

70

60
Percent Ethanol

20

30

40 
The Individual tests were rum in the following manner:

BLOCK TEST

The flims were cast to obtain a final dry rilm of 0.004 inches thlokness on high-grade glossy paper and allowed to dry for 81x hours. Then the films were dry the paper was folded so that two lacquer films were in contact and a laccuer film was next to an uncoated surface of the paper. The test samples were then plaoed in an oven maintained at $125^{\circ} \mathrm{F}$ under a pressure of 1 pound per square inch. The samples were allowed to remain in the oren orernight and were oxamined the following morning for adhesion between the varlous ourfaces after 17 hours testlng. In all ckses, of oourse, adhesion between lacquer and uncosted surfaces mas less than between laoquer surfaces.

PRINT TEST

Wlins were cast on polished plate glass panels. The films were allowed to dry for $81 x$ hours and had a thickness of 0.004 inches. When they were dry a plece of kimpac paper was pleced on the surface under a pressure of 1 pound per square inch. Thls test was run at room temporature. The sample was allowed to romain overnight and examined the following morning after 17 hours testing. Observations were made to 800 whether the kimpac paper adhered to the film or whother it left a print. 


\section{TACK TEST}

Films were cast on high grade slossy paper as before to obtain a flmal flim thickness of 0.004 inohes. After the fIlme were cact they were set aside and allowed to dry for 24 hours then the tackinesa was noted by foeling.

nesults of these throe tests are given in the following tobles and indicate the linits of plasticizers that can be used. 
DATA 
TABLE IV

LIMITS OF PLASTICIZER COHCEMTEATIOH - STANDAED ETHOXY

Plast1c1ser

Dor Plactiolzor 6 Trieresyl Fhosphate Triphonyl Phoephate Dibutyl Phthalate

Dipheryl Phthalato Castor 011

Coooanut 021

Blown Linseed 011

Blown Castor OLI

Butyl Stearate
Blook

30

20

20

20

20

15

20

30

35

20
Print Tack

$30 \quad 45$

$20 \quad 35$

$25 \quad 35$

$25 \quad 35$

$35 \quad 40$

$25 \quad 35$

$40 \quad 60$

$45 \quad 60$

$3545 *$

$50 \quad 60$

TABLES V

LIUITS OF PLASPICIZER CONCENTRATION ${ }^{1}$ - MEDIUR ETHOXY

Plestiolzer

Block

Print

Taok

Dow Plestlalzer 6

35

60

60

Tricresyl Phosphate

30

50

$60 *$

25

45

$50 *$

Dibutyl Phthalate

30

Dipheryl Fithalate

50

$70 *$

$45 *$

Castor 011

30

45*

45*

Coconmut oll

30*

Blown Linceed oil

40

45

60

Blom Castor 011

Butyl Stearate

50

$30 *$

30*

40*

$50 *$

$30 *$

$50 *$

30*

TABLE VI

LIUITS OF PLASTICIZER CONCENTRATION ${ }^{1}-$ LOW ETHOXY

Plastleiser

Dow Plasticiser 6

Trioresyl Fhosphate

Triphony 1 Phoephate

Dibutyl Phthalate

Diphenyl Phthalato

Castor 011

Cooonnut 011

Blown Linseed oll

Blown Castor oll

Butyl Stearate
Block

40

35

35

35

85

35

40

$40 *$

56

35*
Print

50

55

50

50

$35 *$

50

40.

40.

55

35*
Tack

$50 *$

$55 *$

$50 *$

65*

35*

55*

40*

40

55*

35*

1

Plasticizer content, percent of the f1lm.

"lloxt 5\% incroment oaused incompatsbslity, although indiridual test was satiafaotory. 
RESULTS 
The following conelustons can be drawa fron the exporinontal

work:

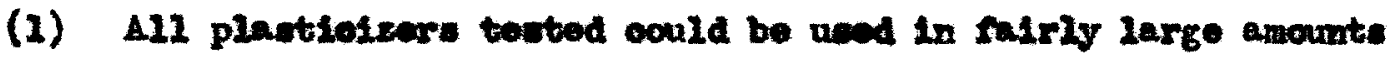

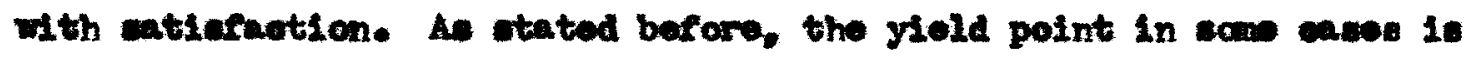

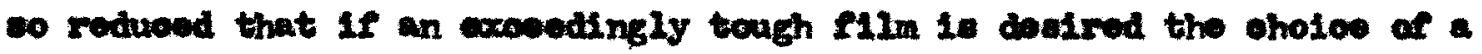
plantielzer in large coneontratien muld be lindted. It was aleo pointed

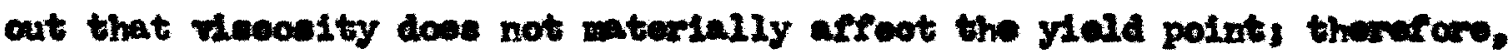

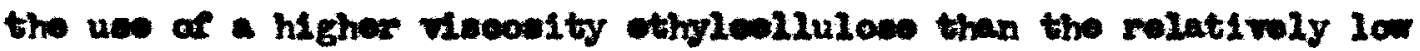
20 ope vesondty material ued hore would show inoreased toughnese with Nutualy the eam yield polnt.

(2) It wa found that "taok by fool" teote are ueually unreliable In drtermining task, but that blowk tosto are highly atiafaotexy, and

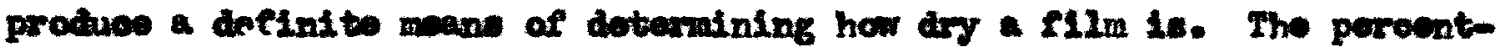

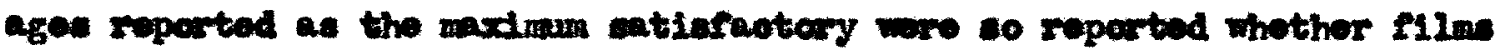
wth an additional $5 \%$ of plaetiolsor were alightly or dofinitoly ottoky. For example. In the cace of dibutyl phthalate and eator oll uning wod-

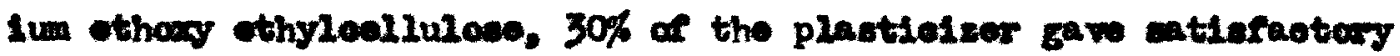
blook toste. Both gawe wats afactory rooulte at $35 \%$ of tetal eollde. yot the dibutyl phthalate was roocudad as having "mueh otielinese on bloek, wile the carter oll had anly a "elight cuount".

(3) Inocuptiblilty wa encountered in coveral Instanose. This wa expoelally true with modium ethoxy and low ethoxy, but was rarely evidenoed when ueing standard othoxy. The starred peroontages listed in the tables are thoes in wioh the eubstitution of another $5 \%$ of plactioizer produed an inocmpatible film yot gave eatiafaotary teots. It wa found that the phosphates oould be inoorporated. 
generally, in much larger proportions than the ofl type plastleizers without provinf incompatible. Incompatibillty was shown by blukhing. greasiness. or crystallisation of the film. Several very interesting film fallures wero obtained. Wost outstanding of the incompatible films was found in the case of butyl stoarste and cocoanut 011. With $40 \%$ cocoanut o11 in modium ethoxy and with $35 \%$ butyl stearate in medium, and $40 \%$ butyl stearato in low, a pronounced blushing resultod. The resulting films were opacue and resembled a white pipmented lacçuer. In the osse of butyl stearate there was a good 5 loss, whlle the cocoanut oll illm had siehtly lese gloss. The film crystellized when using 55\% triphenyl phosphate in nediua ethoxy and $60 \%$ in low ethoxy. The filn uniquely crystallised to a polnt in the center with $80 \%$ triphenyl phosphate in low ethoxy ethylcellulose.

(4) Hagezine covers would require a laçuer coating free from stickiness because the nagazines are bundled for transporting. The block tests would be most significant in this case. rut it must be remembered that the tests were run at $125^{\circ} \mathrm{F}$, a condition that would not be encountered in transporting magazines. In these cases sliphtly more plestlefzer could be used. Fesults of block tests are muoh more definite guantitatively.

(5) Print tests are most important where the finished lasquer surface will be in contact with an unlike material. Furniture and toys are often lacquered and generally are In contact with cloth or come other fabric. There is possibility, too, that a pressure will be applied, and conditions w111 be met siniler to those found in the experimental work. 
Where adhesive tendencies are particulariy desired, the following large percentages of plasticizers might be used with the ethoxy grade given:

Standard Ethoxy

1. 35\% D1butyl Phthalate. 65\% Ethyleellulose

2. $45 \%$ Butyl Stearate, $55 \%$ Ethylcellulose

Kediun Ethoxy

1. 65\% D1butyl Phthalate. 35\% Ethylcellulose

2. 65\% Triphenyl Phosphate. 35\% Ethyloellulose (Incompatible)

3. $70 \%$ Dow Plasticiser 6, 30\% Lthyloellulose (Incompetible)

Iow Ethoxy

1. 80\% Dibutyl Phthelate, 20\% Ethylcellulose (Incompatible)

2. $80 \%$ Castor 011, 20\% Ethylcellulose

Extrome stickiness resulted in the block tests with these comblnations. This condition 80 marked that the folds of paper would not pull apart. Instead the lacquer films adhered so much that the folds of the peper pulled and in layers leaving a portion of the fold cllnging to the other fold and film. Larger percentages, of course, would cause more pronounoed stickiness, but in cases where incompatibility is indicated these oombinations alght be undesirablo. 
EFTECT OF ORAMGE PEELIMG ON TESTS

The flins showed orange peoling in a great many of the nediun ethoxy and low ethoxy solutions resulting no doubt from too rapld eraporation of the solvent. It was thought that this orange peeling might have some influence on the tests and cause unsatisfactory results on block and print when use of a higher bolling solvent combination would give satisfactory tosts. The following $81 x$ solutlons were prepared in order to determine whether or not this was the cases

I. 1. Standerd Ethary. 25\% Dibutyl phthalate

2. Lediun Ethoxy. $35 \%$ Pricresyl Phosphate

3. Low Ethoxy. 40\% castor 011

II. 1. Standard Ethoxy. 25\% DIphenyl Phthalate

2. Mediun Ethoxy. 40; Castor 011

3. Low Ethoxy. 40\% Triphenyl Phosphato

When made wth the regular solvents solutions in Group I did not show orange peeling but gave unsatisfectory results on blook or print tests. Solutions of Group II did show orange peeling with regular solvents and gave unsatiefaotory results on block or print tosts. It was felt that by choosing two suoh groups the tests would be made more general. The percentages were chosen at the turning point, that is. at the peroentage which had just becone unsetiefactory. To make the cheok complete, different types of plastlcizere were chosen. Types celeoted were a phosphate, phthalate, and an oil. Butanol with a bolline point of $117^{\circ} \mathrm{C}$ ws the solvent selected to lessen the rato of evaporation. The following pecial solvent combinations by rolume vere used, 
TABLE VII

SFECIAI SOLVENT COHBINATIONS

$\begin{array}{lll}\text { Peroent } & \text { Peroent } & \text { Percont } \\ \text { Toluene } & \text { Butanol } & \text { Ethanol }\end{array}$

Standard Ethoxy

Modium Ethoxy

Low Bthaxy
70

60

50
20

20

so
10

20

20

The films were cast and found to be free of the objectionable orange peel. Teats on blook and otickinese gave results ldentioal to those on solutions with regular solvent combinations, and demonstrated that the orange peel did not have any influonce in the tests used in this investigation.

MISCELLAUEOOS OBSERVATIONS

Nost Interesting in the tabulated data is the fact that with medium and 10w ethoxy ethyloellulose almost all the tack tests were satiafactory. The material. becam incompatible before the tack point was reachod.

Another interesting point in the experimentel work was the range over wich the butyl stearate had to be taken when using standard ethoxy to reach the 1 imits with wich the teats wero satisfactory. Here the range was $40 \%$, wille with modium othoxy and 10 othoxy there was no range. Tests were discontinued, though satisfectory, because the terials becane inoomatible at 35\% plasticiser with modium othoxy -thyleellulose and $40 \%$ plesticizer wh low ethoxy othyloellulose. 
It was suggested that after only $81 x$ hours of drying in air the flims cast for blook tosts and print tests pight still have retained sow solvent. To oheok this suggestion two groupe of films were prepared. One group was handled the sam as desoribed previously and the other group dried in the oven for 2 hours at $150^{\circ} \mathrm{F}$ and then dried for 4 hours in air. Both groups were put under test at the same time. Results were virtually ldentical, and indicated that there was very little solvent retention.

It was observed than when bluming might have been the result of high humidity, the films on paper still retained gloss but when the solutions we incompatible, the filma on paper had littlo or no gloss. 
SURAARY 
Results of the irvestigation of various plasticlears in solution with ethyloellulose can be sumarised ae followe:

(1) All plastloisors tested can be used in fairly large enounts. Reduction of yleld point and inoreasing softnoss as the percentage of plasticiser increaces, however, would limit the oholce.

(2) Blook tests are usually most rollable in determining tackiness. Taok tests by foel on paper are unrellable.

(3) The cholce of plastioizer is linited by compatibility characterletice in the ouse of adiun othoxy.

(4) The block test is most significant when the finlshed lacquer surface is to be plaoed next to a I1ke surface, as in the case of magazine covers. In ouch instances almost any of the plast10isers would prove sucoessful.

(5) The print tost is nost signifioant when the finished lacquer surfece is to have contact with a different material. The oholoe of plastloliser here wary with the peroentege to be used. (6) Unueual adhesive properties are shown in some instances by dibutyl phthalate. butyl stearate, and castor oil. 
IITERATURE CITED 
1. Bese, Shaller L., and Kaupp1, T. A.. Ind. Eng. Chen.. 29, 678, (1937).

2. Dow Chemical Company. "Ethooel". 1940.

3. Xraus, A., Farbo u Laok, 111, (1935).

4. Van Houckeroth, A. W.. Nat'1 Paint Varnish \& Leoquer Assoo.. C1ro.. No., 481, 162-4, (1935). 
PART II

EFFECT OF ETHYLELLULOSE IN SPIRIT VARNISHES 
IHTRODUCPIOX 
The object of this investigation was to determine the effect of substituting ethyloellulose for resin in spirit varnishos. The effeot was observed by runing abrasion, hardness, cold obook, molsture realatanoe, and molting point doterminations.

Bthylcellulose has found application in lacquers, in folls. in paper coatings, in plastios, in wres, and in rarious other coatings when it was desired to impart some of the distinctive properties of ethyloellulose to the other terlale. Anong these properties are increased toughness, hardness, and molsture restatance. 
31

FISTORICAL 
Ethyloellulose has found appliostion in various coutings. but it has not been employed commerolally in epirit ramiehes. Its use in rarnishos of any type, of course, is limitod because of the relatively low price of rarniches as compared to the price of the cellulose derivative. There may be okses when a all amount of ethylcellulose can be eaployed and certain speoial properties given to the finished coating. A omall differential on the price of the varnish. therefore, would be justifled. 
THEORETICAL 
Varnlshes are grouped into two general classifloationsspirit rarnishes and oleo-resinous varnishes. Spirit varaiches oontain only solvent and natural resin, wille oleo-resinous varnishes contein, besides the solvent, elther natural or gnthotio resins, and 011s. Bocause of the nature of the raw materlals, spirit rarniches are chesper and find appliontion when an inoxpensive ooating which can be supplied in largo quantities is dealred.

Uamy types of matural resins noour in large quantities. These resins are obtainod eithor by tepping the trees or by gatherine the excudations from them. The oleo-resinous varnishes, which are expensive, inolude the rubbing varnishes, furniture and floor varnishes. Anong natural resins used in spirit varnishes are pontianak, manila. damar, shellac, and congo. Pontlanak and wila wore chosen for this work as being representative of natural rosins used industrially.

The resin out of 3.0 pounds per gellon of solvent was chosen as being representative of the cut used in industry. The choice of out depends upon the viscosity and solids content desired for the finishod varnish. 
RAW UATERTALS 
The raw mariels used wore othyloollulose, manila and pontlanak resins, denatured ethyl alcohol, and toluene.

\section{ETHYCELLULOSE}

This merial, supplied by the Dow Chemical Company, was the standard othoxy grade oontaining $48.5 \%$ to $49.5 \%$ othoxy. It had a viscosity of 20 centipoises as deterained on a $5 \%$ by welght solution in 80.20 toluene-ethyl alcohol solvent at $25^{\circ} \mathrm{C}$. The softenine polnt of the othyloollulose 138 to $133^{\circ} \mathrm{C}$ and the molting point was 173 to $165^{\circ} \mathrm{C}(1)$.

MAHILA RESIN

lanila resins belong to the general class of Copal resins and are obtained from the Agathis Alba treo. The resin is obtained either by tapping the tree or by colleoting the exudation resulting from accidental rounding. Further clessifloation of the resin depends upon whether it is gathered from the wound after a few years or dug up after a long period underground. In the latter case the resin is graded aocording to color, s18e, and contanination. The small pale ohlpe, the DBE grade of resin ueed in this investigation contained scae bark and forelgn watter. This resin had a speciflo grarity of 1.06 to 1.07, a coftening point of 78 to $88^{\circ} \mathrm{C}$, and a melting point of 120 to $129^{\circ} \mathrm{C}$.

\section{POATIANAX RESIN}

Pontianak is a seat-foseil oopal belonging to the manila 
group of resins. It is the oxuded materlal gathered from the wound after fow yoars. After the rosin is gathered it is graded accordIng to color. 180, and contanination.

The chip form used in this investigation had speolfio gravity of 1.07 to 1.08 , e softening point of 82 to $132^{\circ} \mathrm{C}$, and a molting point of 136 to $156^{\circ} \mathrm{C}$.

BTHYL ALCOHOL

The denatured ethyl alcohol had a speciflo gravity of 0.789 and a boiling point of $78.4^{\circ} \mathrm{C}$.

TOLUERE

The toluene had a specifio grarity of 0.866 and a bolling point of $111^{\circ} \mathrm{C}$ 
EXPERIMENTAL 
Vany mothods of tosting coatings including paints, varnishes, and lacquers have been devised to compare phyalcal properties of their 111ms. The effect of operating oonditions and the varied equipwont arallable make it impractlcable to get more than relative teat of a series of paint compositions. In this research spirit rarnishes containing varying peroentages of ethylcellulose were compared. Varnishes wore made using pontienak and manile resins and the following tosts wore runt

(1) Abrasion Rosistanoe

(2) Fin rineas

(3) Cold Chook

(4) Nolting Point

(5) Moisture Resiatanee

ABRASION RESISTARCE

The abrasion resiatanoe or abresion ralue of a film has been determined in several ways by otiher experimonters. The abrasion factor Is influenced by several conditions. Sohuh and Kern (5) have notod several contributing factors such as relative humidity and temperature, particle ize of abrasive, rate of flow of particles, air pressure, the anglo of inclination of panel. It mast be remombered. though, that resistanoe to abrasion is not the same as resistance to roar. beosuse the latter inoludes several factors besides resiatance to abrasion. It Is cometimes true that films having great abrasion resistance are often soft, and so there is no direct connection between abrasion resistanoe and hardness. 
Sereral abrasives and mothode were avallable for the tests. As outlined by Gardner (3) abrasives that oan be used Include oarborundum partioles, Ottawa sand, and more reoontly, artifiolal alumimum oxide. Hothods of Xooh (4) and others conclude in either measuring the anount of abrasive used to wear away the ooating, or deternining the 1068 in weight of the coating. The method of testing depends, in some cases, upon the use to whioh the fimal paint is to be subjected. Thus, In testing traffic paints, a solid rubber tire rotating at 2000 r. p. me has been employed, whlle the modified Dorry apparatus used by the How York State Divioion of Fighways for highway traffic paints ut11izes a revolving abrasive material.

The use of carborundun has been adrooated on the basis that it flows more froely than othor materials and is not affected by nolsture; however, It has a tondenoy to shatter. Sand in some cases does not give a rapid enough test. but was oelected as the matorial to be employed hero.

In this investigation abrasion rosistance was determinod by allowing dry ottawa sand to fall froely through 1 foot lomgth of 8 me glass tubing onto a glass panel coated with the varnish to be tested. The arerage particle size of the sand was 1 me and the glass panel was inolined at an angle of $45^{\circ}$.

The weight of and needed to wear fust through the f1Im was determined, and the thickness of film at the point of failure was moasured. The abrasion value of the film was recorded as the weight in grams of sand noeded to wear through a film of 0.0010 inches in thiokness. 
BARDMESS

As stated proviously a flin having great abrasivo resistanoe aight be soft. However. similar effects to those obteined in abrasion testa are noted in hardness tests when varying the relative humidity and temperature. Hardness teste are dirided by cardner (2) into throe general procedures:

(1) Scratoh Hardness

(2) Pendulum Hardness

(3) Indentation Fiardnees

In coratoh hardnoss points of varlous abrasive materials such as oteel pointe. lead penoils, and steel knives are dram over the couting and the result becomes the hardnos of the abrasive necessary to out through the film.

Pendulua hardness ut1lizes a awinging beam or two parallel rooking ring known as the Sward Rocker.

Indentation hardness tests include the Pfund, in wich the load necessary to produo a certain indentation by aphorical tool is masured, and Inprint tosts wioh use a cloth terial to form a print on the couting.

There is very little correlation betwoen the rarious hardness tests.

The soratoh hardness method used here. In this test Vemus drawing pencils were drawn over the films of equal thioleness cast on plate glass. The hardness of the lead inoreases with inoreasing $B$ number. The pencils wore held at an angle of $45^{\circ}$ and ordinary witing prossure used. Those fllns, whioh were harder 
than the lead showed only a black mark on the surface. Films softer than the load were soratohed, and the seteriel was torn away from the glass panel. Hardness was recorded as the muber of that peno1l noeded to soratoh the surface.

COLD CHECK

Steel panels on which the varnish fllms had been east to -qual thiaknoss wore alternated botween an oven maintained at $120^{\circ}$ to $125^{\circ} \mathrm{F}$ and a cold box maintalned at $25^{\circ}$ to $30^{\circ} \mathrm{F}$. Panels were left In oach ohamber for periods of an hour and examined after each cyole. The oycle number on whioh definite cheoking of the f1lm occurred as recorded as the point of fallure. All panels were subjected to twolve oomplete cyoles whether or not they had failed on an carlier oyele.

UELTING POINT

Virtually all mothods used in determinting the molting point of a resin employ a mercury layer over a resin plue in a tube. The resin upon selting rises to the surface of the mercury. The melting temperature is recorded as the tomperature at whloh the resin appears on the top of tho mercury layer. The famlilar ball and ring method 1. st111 another way of determining melting point.

In this work the mothod was much simpler. The dry film was powdered and placed in a caplllary tube in an oll bath. The 011 wented and the fusion range of the material recorded. 
MOISTURE RESISTANCE

Varnish films of ecual thickness were cast on plate glass panels and lumersed in water for 24 hours. The panels were then removed and exalned for effects of the water on the film. They were rated numerically in the order of their discoloration. After perlod of drying in alr the flims were again examined to determine whether any had returned to the original state. 
PROCEDURE 
The procolure in each of the varnish series was at follows:

The resins were dissolved in aloohol and the ethyloellulose In toluene by tumbling on roller mill. When thoroughly mixed, the two separato portions were combinod and suffiolent solvent was added to bring the cut to 3.0 pounds of resin per gallon of solvent. The nixture was made homogeneous by further tumbling and then filtered to remove the dirt and insoluble materials. The solvent consisted of 75\% alcohol and $25 \%$ toluene by volume.

F1 Ine were prepared on glase for moisture resistanoe. abrasion resistance, hardness tests, and on steel panels for cold cheok tests. They wore cast to equal thicknoss, and in the case of abrasion resistance the thiokness was mosured. 
DATA 
PERCEMT ETHYCELLULOSE

$\begin{array}{llllll}0 & 5 & 10 & 15 & 20 & 25\end{array}$

ABRASION RESISTAKCE

Grams of sand required to penotrate film of

$\begin{array}{llllll}24 & 40 & 1920 & 5280 & 8250 & 9800\end{array}$

$0.0010^{\prime \prime}$ thickness

HARDWESS

Verms Penoil humber

$3 \mathrm{H}$

$4 \mathrm{H}$

4 II

4 III

5II

COLD CHECX RESISTANCE

Cold oyele on which

definite fallure

oocurred

UELIING RANGE

Degreos Centigrade

14314

to to

153156

149

151

153

to

155

to

to

163

to

165

MOISTURE RESISTANCE

Order of Resistanoe

4th 3rd 2nd let lat let

MANILA VARNISIES

PERE ERT ETHYLCELUULOSE

0

6

10

$15 \quad 20$

25

ABRASION RESISTANCE

Grame of sand required

60

68

4230

7320

11416

13410

to penotrate film of

$0.0010^{\text {" thiolness }}$

EARDNESS

Vemus Penc11 Thuber

2 II $3 \mathrm{H}$

3H

$4 \mathrm{H}$

4 III

5H

COLD CIECK RESISTAWLE

cold oyole on which

definite failur.

$\$ 410$

$11 \quad>12 \quad>12$

occurred

UELTIKG RAMGE

Degrees Centigrade

120

$+$

130

128

to

128

132

136

140

138

to

to

to

MOISTURE RESISTARCE

Order of Resistanoe

4th 3rd 2nd 1st lst Ist 
KESULTS 
ABRASION FESISTANCE

A definite increase in abrasion resistance was obtained by substitution of ethylcellulose. This increase became very pronounoed when at least $10 \%$ of ethylcellulose had been incorporated. HARDNESS

Hardness of the filme of varnishes conteining ethylcellulose increased as more ethylcellulose was subatituted. This is show by Increase in ponoll number.

COLD LIEK

A gradual inorease of reslotance to cold check was noted upon substitution of ethyloellulose. Eren after 12 oycles the manila varnishes containing $20 \%$ and $25 \%$ ethylcellulose had not failed.

IALLTHG POTNT

As ethylcellulose was substituted the "nelting, range"

rose. A "melting range" was obtained because with auch materials it is impossible to get a definite fusion point.

MOISTURE RESISTAICE

The effect of molsture on the films was in all cases show by a discoloration. which in the worst instances becane a pronounced blushing. Adhesion to the glass panel was also materlally reduced and in some cases, the film becane completely detached from the panel. Filns that conteined no ethyloellulose showed rarked 
discoloration. while those containing $5 \%$ and $10 \%$ ethylcellulose wero slightly discolored. Those containing $15 \%$ and more ethyloellulose were not alscolored. After inmerston the panels were dried in air and examined for permanent discoloretion. Those varnishes that contained ethylcellulose regained their orifinal appearance while those without ethylcellulose retained the discoloration. 


\section{1}

LITHSATUEE CITED 
1. Dow Chenteal Company. "Ethocel", 1940.

2. Gardner, Henry A. "Physical and Chemical Eramination of Feints, Varnishes, Laequers and Colors", 9th Edition, page 112, hay, 1939.

3. ibid., page 128 .

4. Roch, Hillam, Ind, kng. Chem., Anal, Ed., 2, 407 (1930).

5. Schuh, A.E*, and Kern, E. H., Ind, Trg. Chem, Am 1. Ed.: 3. $72(1931)$. 
APPENLIX 
The author has undertaken a atudy of the reaction involved when ethyloollulose is incorporatod into a varnish. The object in this investigation is to deternine whether there is merely a physical dispersion or actually a chenical roaction. The - irmple constituents of a varnish were selected as raw materials. These were oleic acid, Iinole1c acid, and soybean oil. Ethylcollulose to be used is of standard and medium ethoxy grade, of 7 and 145 contipoise viscosity types. The solvent to bo enployed is diethyl benzene. The following procedure for oleic acid is to be used in generwl for the other materials:

1. Heat together 30 parts ethylcellulose and 70 parts diethyl bensone to drive off all air and water.

2. Heat together 30 parts oleic acid and 70 parts dlethyl bensene to drive off all alr and water.

3. Hix equel perts of both of these mixtures and reflux. Run viscosity detorninations overy ton minutes, and discontinue heating when viscosity has reached a minimum.

4. Calculate the percentage of fatty acids rencted from the arzount of water collected.

5. Determine acid number and saponification number of the nixture.

6. Steam distil off the solvent from sone of the mixture. Saponify this residue with alooholio caustio, add water, and boll off the alcohol. Filter and sasi the precip1tate. Determine the percentage ethoxy of the dry proolpitate.

The procedure outlined will indicate the following:

1. Aold that have combined with the othyloellulose will be determined by the differenoe between acid number and saponification number, 
2. The amount of water collected and the differenoe between saponifleation and acid numbers will indicate whother there is wore reaction of ilich viscosity than low visoosity ethyloellulose. If there 1s more reaction it will show that the addition takes place wherever the cellulose chain is broken.

3. Esterifleation of unethylated hydraxyl group w111 be incicated by more reaction of medium ethoxy than standard ethoxy ethylcellulose.

4. Splittine off of ethoxy groups will be indicated by reduction of percentage ethoxy as compared with the original ethylcelluline.

Th1s work is now in progress and is bolag carried on by Mr. Virgil R. Hulette, Jr.. the Dow Chemical Company Fellow for 1940-41. 


\section{ACKNOHLEIXGLENTS}

The Author whes to thank the Dow Chemioal Company for the grant that made these two investifations possible.

He also wnts to express his appreciation to kx. John Bright Tepe with whor the work on spirit varnishes wes perforwed, and to Mr. F. R. Collings, Mr. J. L. Sherk, and Ir. Norman Peterson for their helpful sugrestions durinf the progress of the work. 
VITA

Ira Walter Mutchison, Jr., was born in Loulsville, Kentucky, on July 20, 1914, the Bon of Ire Falter futchison, Sr., and Corino Bender Futchison. He recelved his primsy and high school education in the public schools of Louibvillo and cleveland, Ohio, and a busIness school training at the Clark College of Comerce, Louleville. A1l of his college work wes cerried on at the University of Louls71110. He received a Bachelor of Chomical Ingineering Degree in Juno. 1939, and a Haster of Chomical Engineering Degree in June, 1940. He was awarded the Dow Chemical Company Fellowship for the yoar 1939-1940, and upon comletion oi his acadenie work was employod by the fow Chenical Company at the plant in sidaland, Michizan. Mr. lutchison is a nember of Signe Tau, national honorary onglneering fraterulty, and Thete chi iolta, national honorary chemistry fratemity. He was secretary of the student chafter of the American Institute of Chemical Inrinoers, and historian of the Onicron chapter of signa Tau.

Ilo is co-author of the paper. "Ihe Fybical Fropertios of the Ternary System Butyl Alcohol-Ethyl Aoetato-Toluene" which appeared in the Warch, 1940, 18sue of the Journel of Myyical Chemistry. 